\title{
Chain Length Diversity of Sialic Acids and Its Biological Significance
}

\author{
ジシアル酸・オリゴシアル酸・ポリシアル酸の生物学的機能
}

\author{
Sato, Chihiro \\ Graduate School of Bioagricultural Sciences, Nagoya University, Chikusa, Nagoya 464-8601, JAPAN \\ FAX: 81-52-789-5228, E-mail: chi@agr.nagoya-u.ac.jp
}

Key Words: disialic acid, oligosialic acid, polysialic acid, sialyltransferase, siglec

\begin{abstract}
Sialic acids are commonly present as monosialyl residues at the non-reducing terminal end of glycoconjugates. In some cases, $\alpha 2 \rightarrow 8$ linked di/oligosialic acid chains with DP 2 or 3 sialic acid residues are common structural units of gangliosides, and involved in various biological processes, such as cell adhesion, cell differentiation, signal transduction, and surface expression of stage specific antigen. In contrast, little attention has been paid to the occurrence and functions of such short sialyl di/oligomers on glycoproteins, while polysialic acid (DP $\geq 8$ ) in embryonic NCAM has been extensively studied as a regulator of cell adhesion in neurogenesis. As analytical methods to detect di/oligosialic acid structures have been improved, several glycoproteins containing di/oligo/polysialic acid chains have been identified. It is thus hypothesized that these di/oligosialic acid residues on glycoproteins may have similar important functions in common with those proposed for the gangliosides or may have new functions. Currently, several studies showing the importance of di/oligosialic acid-containing glycoproteins have emerged. In this review, recent advances in such studies of di/ oligosialic acid residues on glycoproteins, including analytical methods, occurrence, biosynthetic pathways, and functions, are described.
\end{abstract}

要 約

糖鎖末端には通常 1 残基のシアル酸が存在するが、そのシ アル酸残基の上にさらに数残基のシアル酸が直鎖状に縮重合し てシアル酸重合体を形成する場合がある。 $\alpha 2 \rightarrow 8$ 結合ジシアル 酸 (重合度 $\mathrm{DP}=2$ ) 構造はガングリオシドの構成成分としてよく 知られており、細胞接着、細胞分化、シグナル伝達、時期特異 的発現など、多くの生物学的機能を果たしている。また重合度 が 8 以上のポリシアル酸構造は神経細胞接着分子上に存在して おり、発生や分化に関わることが知られている。しかし、重合 度が 2 から 7 程度のジ・オリゴシアル酸構造をもつ糖タンパク 質の存在や機能についてはこれまでほとんど注目されて来な かった。しかし近年、ジ・オリゴ・ポリシアル酸 (シアル酸重合 体) 構造を微量検出する手法が改良され、天然にジ・オリゴ・ポ リシアル酸含有糖タンパク質がこれまで知られている以上に数 多く存在することが明らかにされてきている。そのため糖タン パク質上のシアル酸重合体構造が、既にガングリオシドにおい て明らかにされてきた機能の一端を担う可能性が、また従来考 えられてきたこととは全く異なる新たな機能を担っているこ と、さらには新たなポリシアル酸の機能が明らかになってくる かもしれない。この総説ではシアル酸重合体の分析法、生合 成、存在、機能における最近の知見を述べる。
The sialic acids are a family of 9 -carbon carboxylated sugars. $N$-acetylneuraminic acid (Neu5Ac), $N$-glycolylneuraminic acid (Neu5Gc) and deaminoneuraminic acid (KDN: 2-keto-3deoxy-D-glycero-D-galacto-nonoic acid) whose 5-C is substituted by the acetoamide, hydroxyacetoamide, and hydroxyl group, respectively, are the three major sialic acids in nature (Fig.1). Diversity in these structures arises by acetylation, sulfation, methylation, lactylation, and lactonization and almost 50 members have been so far identified $(1,2)$. In most cases, the sialic acids are present as monosialyl residues at the non-reducing terminal position of glycan chains of glycoproteins and glycolipids. Sialic acids play important roles in ligand-receptor binding and cell-cell and cell-extracellular matrix interactions during fertilization, embryogenesis, and differentiation $(1,3)$. Recent discoveries of sialic acid-binding animal lectin family
シアル酸は 9 炭糖の一員であり、 5 位の置換基が $N$-アセチ ル基である $N$-アセチルノイラミン酸 (Neu5Ac)、 $N$-ヒドロキシア

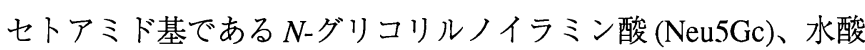
基で置換されたデアミノノイラミン酸 (KDN; 2-ケト-3-デオキシD-グリセロ-D-ガラクト-ノノン酸) が 3 大分子種である。またシ アル酸の置換体は、水酸基のアセチル化、硫酸化、メチル化、 ラクチル化あるいはラクトン形成など、これまでにほぼ50 種類 同定されている $(1 、 2)$ (図 1)。一般的に、シアル酸は糖タンパク 質や糖脂質において糖鎖の非還元末端部位にモノシアリル基と して存在しており、受精、発生、分化過程においてリガンド-受 容体および細胞-細胞間相互作用において重要な機能を果たして いることが明らかになっている $(1 、 3)$ 。特に最近のシアル酸結合 性動物レクチンファミリーであるシグレックの発見 (4) とその 
(siglec) have further emphasized the biological function of sialic acids $(4,5)$. The functional importance of sialic acids has been also demonstrated by the fact that mice deficient in UDP- $N$ acetylglucosamine 2-epimerase $/ \mathrm{N}$-acetylmannosamine, which is the key enzyme in the de novo synthesis of sialic acids are embryonic lethal (6).

Sialic acids are commonly present as monosialyl residues at the non-reducing terminal end of glycoconjugates. In rare cases, the sialic acids are linked to each other to form a polymerized structure, polysialic acid (7). Polysialic acid chains in nature usually have a degree of polymerization (DP) ranging from 8-200 sialyl residues. Only four glycoproteins have been identified as polysialic acid-containing glycoproteins until recently (7). Polysialic acid is first identified in the glycocalyx of neuroinvasive bacteria (8) and considered to be involved in the invasion into the brain. In vertebrates, neural cell adhesion mol-
クローニング (5) によって、シアル酸の機能的重要性に対する 認識はさらに高まっている。さらに近年の、シアル酸 de novo 生 合成を司る UDP- $N$-acetylglucosamine 2 -epimerase $/ N$ acetylmannosamine kinase の遺伝子改変マウスが胎生致死 (6) で あるとの結果からもシアル酸が発生に果たす役割の大きさがう かがえる。

シアル酸残基は通常、 1 残基が糖鎖の最外部に結合したモ ノシアル酸として存在するが、まれにその末端シアル酸残基の 上にさらにシアル酸の直鎖ポリマーが結合するポリシアル酸構 造として存在する場合がある (7)。重合度が 8 以上のポリシア ル酸にをもつ分子として最近まで 4 種類のみが知られていた (7)。初めに見つかったのは、神経侵襲性バクテリア (脳髄膜炎 細菌)の莢膜多糖であり (8)、ポリシアル酸は脳への侵入に関与 する。また、脊椎動物では、神経形成期における神経細胞接着 分子 (NCAM) (9)、電気ウナギの電圧感受性ナトリウムチャンネ ル (10) および魚卵の分泌顆粒局在糖タンパク質であるポリシア
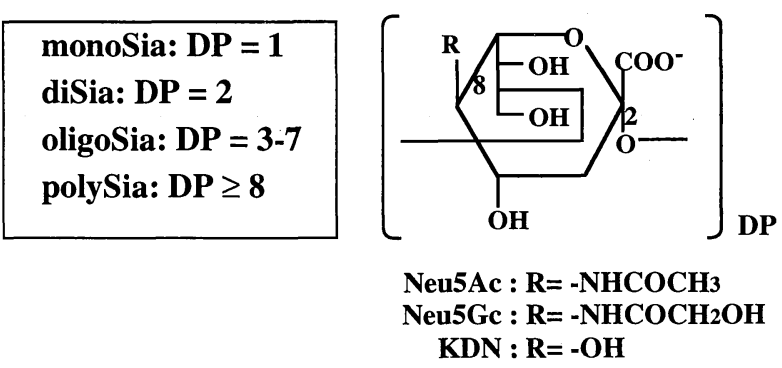

Fig. 1. Structure of sialic acids and definition of mono/di/oligo/polysialic acid. DP, degree of polymerization.

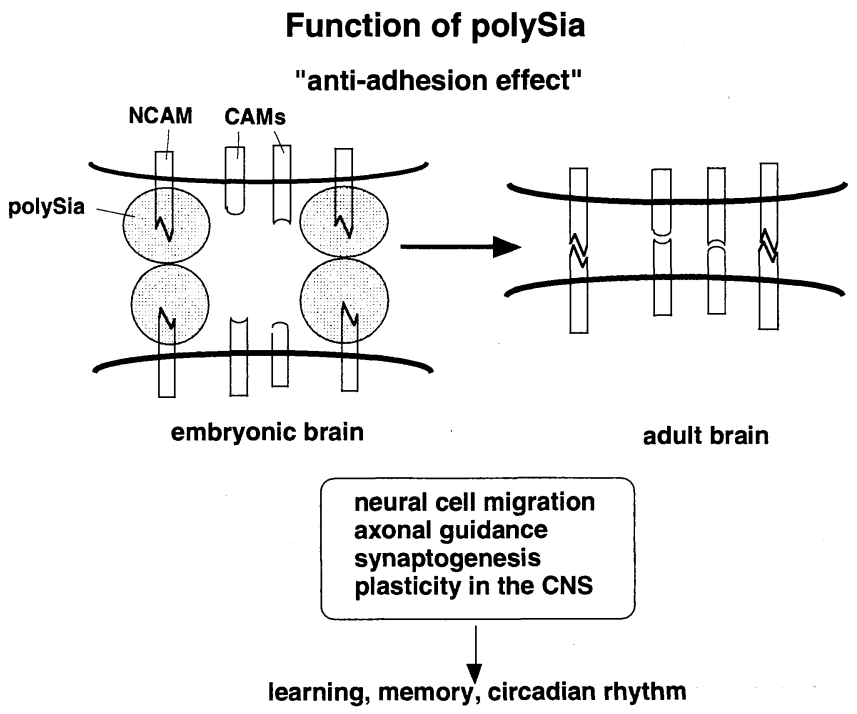

Fig. 2. Functions of polysialic acid chain linked to NCAM. In neural cell-cell interaction in embryonic brain, NCAM bearing the polysialic acid chain cannot bind to NCAM and prevents other CAMs from binding with each other due to the bulky space occupied by polysialic acid chain (anti-adhesive effect). Therefore, in the embryonic brain, neurons can reach ideal zones without formation of an ectopic synapse. In the adult brain, NCAM and other CAMs can restore their binding abilities and cells settle as a result. Thanks to the expression of polysialic acid chain at a spacio-temporally specific stage, normal neurogenesis and synaptic function are facilitated and learning, memory and circadian rhythm are maintained normally. 
ecule (NCAM) (9), a voltage-gated sodium channel of eel (10), and fish egg polysialoglycoprotein (PSGP) (11) are known to be modified by polysialic acid residues. Studies on NCAM showed that polysialic acid chains are regulatory molecules in cell-cell/matrix interaction via anti-adhesive effect during neurogenesis (12) (Fig.2). Polysialylation occurs in some tumors and is involved in metastasis (13).

On the other hand, little is known about glycoproteins containing the short sialyl oligomer, whose DP is between mono and poly, i.e., disialic acid ( $\mathrm{DP}=2)$ and oligosialic acid $(\mathrm{DP}=3$ 7) (Fig.1). In recent years, we have developed sensitive chemical methods to detect the sialyloligo/polymer (14-16), and have shown the presence of di/oligo/polysialyl residues in nature $(16,17)$. In this minireview, the latest topics of di/oligo/polysialic acid on glycoproteins will be introduced.

\section{A. Development of Sensitive Chemical and Immunochemi- cal Detection Methods}

When samples containing 10-100 $\mu \mathrm{g}$ of di/oligo/ polysialic acid structures are analyzed, conventional methods including methylation analysis (18), nuclear magnetic resonance (NMR)(19), and mild acid hydrolysis-thin-layer chromatography (TLC) (20) can be applied. For samples containing a very small amount of the di/oligo/polysialic acid residues (less than $1 \mu \mathrm{g}$ ), as is often the case, conventional methods (described above) cannot be applied. Instead, the following highly sensitive, chemical and biochemical methods are useful, and these methods have successfully confirmed the ubiquitous occurrence of tiny amounts of di/oligosialic acid (fmol) in glycoproteins.

\section{A-1. Chemical Analyses}

Fluorometric $C_{f} C_{9}$ Analysis (14): When an oligo/polymer of $\alpha 2 \rightarrow 8$-linked $N$-acylneuraminic acid (Neu5Ac or Neu5Gc) residue is subjected to periodate oxidation, the non-reducing terminal residue is oxidized to the $\mathrm{C}_{7}$ analogue of $\mathrm{N}$-acylneuraminic acid, $\mathrm{C}_{7}(\mathrm{Neu} 5 \mathrm{Ac})$ (5-acetoamido-3,5-dideoxy-L-arabino-2hepturosonic acid), or $\mathrm{C}_{7}$ (Neu5Gc) (5-hydroxyacetoamido-3,5dideoxy-L-arabino-2-hepturosonic acid) from Neu5Ac or Neu5Gc residues, respectively. On the other hand, internal residues of Neu5Ac $\left(\mathrm{C}_{9}(\mathrm{Neu} 5 \mathrm{Ac})\right)$ or Neu5Gc $\left(\mathrm{C}_{9}(\mathrm{Neu} 5 \mathrm{Gc})\right)$ remain intact (21). Accordingly, the detection of $\mathrm{C}_{9}$-compounds in the periodate oxidation products would strongly suggest the presence of internal sialyl residues or oligomeric structure of $\alpha 2 \rightarrow 8$-linked $N$ acylneuraminic acid therein. Fluorescent-labeled $\mathrm{C}_{7}$ - and $\mathrm{C}_{9}$-compounds with 1,2-diamino-4,5-methylenedioxybenzene (DMB) (22), which is an $\alpha$-keto acids-specific labeling reagent, are quantified by fluorometric high performance liquid chromatography (HPLC) (23).

Mild Acid Hydrolysis-Fluorescent HPLC Analysis (15): A series of oligo/polymers produced by mild acid hydrolysis of an oligo/polySia chain are directly labeled with DMB and analyzed on an anion-exchange HPLC. The DMB-labeling is ap-
ロ糖タンパク質 (PSGP) (11) にその存在が知られている。現在、 NCAMを中心にした研究の結果から、ポリシアル酸は、細胞と 細胞、細胞と細胞外マトリックスの間の接着を阻害的に制御し て神経形成に関与する分子であると認識されている (12) (図 2)。 またある種の腫瘍細胞で発現しており、癌転移にも関与するこ が示されている (13)。

一方、モノシアル酸とポリシアル酸の中間的な鎖長をもつ シアル酸鎖、ジ (重合度 2)・オリゴシアル酸 (重合度3 7) 構造 (図 1)の存在は、糖タンパク質においてはほとんど知られてい なかった。しかし近年、我々がその微量検出法を開発して (1416) 存在検索を行った結果、様々な組織の糖タンパク質において 広く存在することが明らかになった $(16 、 17) 。$

本稿では、タンパク質上に扔けるジ・オリゴ・ポリシアル 酸を中心に最新のトピックスを紹介し、このようなシアル酸の 鎖長多様性の生物学的意義と今後の研究課題について述べる。

\section{A. 微量検出法の開発}

マイクログラム程度のシアル酸重合体エピトープを持つサ ンプルを解析するときは、メチル化分析法 (18)、NMR 測定法 (19) 、緩和酸水解-TLC 分析法 (20) といった従来法を用いるこ とができる。しかしこのようなエピトープを持つ糖タンパク質 は、しばしば非常に微量であるため従来法では解析が難しいこ とがある。そこで我々はこれらの糖鎖エピトープを検出する高 感度な化学的手法と免疫化学的手法を開発し、化学的手法と免 疫化学的手法を組み合わせて用いることによって、fmol 程度の 微量なジシアル酸、オリゴシアル酸、ポリシアル酸糖鎖エピ トープの解析が可能にした。

\section{A-1. 化学的検出法}

蛍光 $C_{f} / C_{9}$ 分析法 (14) $: \alpha 2 \rightarrow 8$ 結合 $N$-アシルノイラミン酸 (Neu5Acyl) の重合体構造を過ヨウ素酸酸化すると、非還元末端 残基は酸化され $N$-アシルノイラミン酸の $\mathrm{C}_{7}$-アナログを生じる。 つまり Neu5Ac 抢よびNeu5Gc からそれぞれ C 7 (Neu5Ac) (5-ア セトアミド-3,5-ジデオキシ-L-アラビノ-2-ヘプツロソン酸) また は $\mathrm{C}_{7}$ (Neu5Gc) (5-ヒドロキシアセトアミド-3,5-ジデオキシ-L-ア ラビノーヘプツロソン酸)が生じる。一方、内部の残基はイン夕 クトな Neu5Ac $\left(\mathrm{C}_{9}(\mathrm{Neu} 5 \mathrm{Ac})\right)$ または Neu5Gc $\left(\mathrm{C}_{9}(\mathrm{Neu} 5 \mathrm{Gc})\right)$ のま まである (21)。したがって過ヨウ素酸酸化物において $\mathrm{C}_{9}$ 化合物 が検出されるということは、その試料に、内部の $\alpha 2 \rightarrow 8$ 結合 $N$ アシルノイラミン酸残基の存在、すなわち $\alpha 2 \rightarrow 8$-結合シアル酸 重合体の存在を強く示唆する。 $\alpha$ ケ酸を特異的に標識する試 薬である 1,2-ジアミノ4,5-メチレンジオキシベンゼン (DMB) (22) で蛍光標識した $\mathrm{C}_{7}$ 化合物䇽よび $\mathrm{C}_{9}$ 化合物は、逆相高速液体ク ロマトグラフィー (HPLC) で分離・定量される (23)。

緩和酸水解-蛍光 HPLC 分析 (15)：シアル酸重合体の緩和酸 水解によって生成される一連のジ・オリゴ・ポリマーを DMB 試 薬を用いて直接ラベルし、陰イオン交換 HPLCによって分析す 
Trends in Glycoscience and Glycotechnology Vol.16 No.91 (September 2004) pp.331-344

plicable to detection of various types of oligo/polymers of sialic acids found in glycoconjugates, which differ in the component sialic acid species, the inter-residual linkage, and DP. These analyses can be applied to glycoproteins blotted on the PVDF membrane.

\section{A-2. Biochemical Analyses}

Specific Antibody: Antibodies are powerful tools for the structural and functional analyses of various glycotopes. It is most important to understand the precise specificity of the antibody recognition, if the antibody is used for structural determination of carbohydrates. We determined the immunospecificity of so-called anti-polysialic acid antibodies and newly developed antibodies by an ELISA-based method using a series of oligo/ polysialic acid-conjugated phosphatidylethanolamine with the defined sialic acid composition and DP as the test antigens (24). Using this method, the precise immunospecificity of various antidi/oligo/polysialic acid antibodies has been successfully separated into 3 groups based on the DP and non-reducing terminal end for antibody recognition (16,17). Group I antibodies are the "anti-polysialic acid antibodies" that recognize chains of $\alpha 2 \rightarrow 8$ linked sialic acid with DP 8 or greater sialic acid residues, including fully extended polysialic acid chains. These antibodies recognize the helical conformation formed by sialic acid residues within the internal region of the polysialic acid chains. The non-reducing terminal residues are not involved in antigen recognition. Group II antibodies, designated "anti-oligo+polysialic acid antibodies," recognize both oligosialic acid with DP 2-7 and polysialic acid chains. These antibodies recognize the distal portion of oligo/polysialic acid chains, including the non-reducing termini. Group III antibodies, designated "anti-oligosialic acid antibodies," recognize oligosialic acid with DP 2-4, but do not bind polysialic acid. These antibodies appear to recognize specific conformations of di/oligosialic acid with DP 2-4.

Specific Enzyme: Endo-sialidase (Endo- $N$ acylneuraminidase, Endo-N) that selectively cleaves $\alpha 2 \rightarrow 8$ linked polysialic acid chains (25), and linkage-specific exosialidases that hydrolyze the sialic acid residue from the nonreducing termini are two enzymatic probes. The Endo-N can cleave the pentamer of sialic acid. There are another two endo$N$-acylneuraminidases whose specificities are DP $\geq 11$ and DP $\geq 3$ $(26,27)$. Recently, the linkage-specific sialidases are easily available (for example, $\alpha 2,3$-specific sialidase and $\alpha 2,3 / \alpha 2,6$-specific sialidase) (28). We can determine di/oligo/polysialyl structure more precisely by the combinational application of specific antibodies and specific enzymes.

\section{B. Occurrence of Di- and Oligosialic Acid Structures on Gly- coproteins}

We searched for the di/oligo/polysialic acid residues on glycoproteins in mammalian tissues and cells using these sensitive chemical and immunochemical methods. An extremely large
る。この方法は非常に簡便であり、複合糖質中に見いだされる 構成シアル酸、内部シアル酸の結合様式、重合度 (DP) が異なる 様々な種類のシアル酸オリゴ・ポリマーに適用できる。これら の方法は SDS-PAGE で分離し、PVDF 膜にブロットした非常に 微量な試料にも適用できる。

\section{A-2. 免疫化学的分析 (特異的抗体と醅素)}

多くの糖鎖エピトープの構造的、機能的研究に抗体は有用 である。しかしそのためには厳密な抗体の特異性の解析が必要 である。これまでに開発された抗体の精密な特異性を、一連の 重合度をもつ共通な合成脂質結合ジ・オリゴ・ポリシアロ糖抗 原 (24) を用いて調べた結果、抗体認識に必要な重合度と非還元 末端残基の必要性に基づいて、3つのグループに分けることが できる $(16 、 17) 。$ 実際、それぞれを用いて、重合度を予測するこ とが可能になった。グループI抗体は長く伸長した、DPが 8 以 上のポリシアル酸鎖を認識する“抗ポリシアル酸抗体”である。 これらの抗体はポリシアル酸構造の内部領域のシアル酸残基に よって形成されるヘリックス構造を認識する。非還元末端は抗 体の認識に関与しない。グループ II 抗体は DP 2７ 9オリゴシ アル酸とポリシアル酸鎖の両方を認識する “抗オリゴ+ポリシア ル酸抗体”である。これらの抗体は非還元末端を含むオリゴ・ポ リシアル酸構造の末端部位を認識する。グループ III 抗体は DP 2〜4のジ・オリゴシアル酸のみを認識し、ポリシアル酸を認識 しない“抗オリゴシアル酸抗体”である。これらの抗体は DP 2 4 のオリゴシアル酸の特異的立体構造を認識することがわかっ ている。

シアル酸重合体に高い特異性を持つ酵素として、エンド- $N$ アシルノイラミニダーゼ (Endo-N) (25) と結合位特異的シアリ ダーゼがある。N-アシルノイラミン酸のペンタマー構造がEndo$\mathrm{N}$ の認識に必要な最小単位である。他にも基質特異性が異なる 二種類のエンドシアリダーゼ(切断に必要な最少重合度はそれぞ れDP $\geq 11 、 \mathrm{DP} \geq 3)(26 、 27)$ が現在までに見つかっている。ま た、近年では基質特異性が異なるエキソシアリダーゼ $(\alpha 2,3$, $\alpha 2,6$-特異的シアリダーゼ、 $\alpha 2,3, \alpha 2,6, \alpha 2,8$ 特異的シアリダーゼ など) (28) が利用可能となり、これらの酵素と抗体を用いること によって、シアル酸重合体の厳密な構造決定が可能になった。

\section{B. 糖タンパク質におけるシアル酸重合体の普遍的存在}

これらの方法を用いて、哺乳類の種々の臟器や細胞におい てジ・オリゴ・ポリシアル酸構造を検索した。その結果、シア 儿酸重合体構造を持つ糖タンパク質が天然に広く存在分布する ことが明らかになり、さらに種々の担体タンパク質が同定され た。脳においては、成体型 NCAM (17)、CD166 (29) にジシアル 酸構造が存在する。また、血清では、フエツイン $(30) 、 \alpha_{2}$-マク ログロブリン (30)、脂肪の代謝や動脈硬化、糖尿病の発病に深 く関わる脂肪細胞由来の新しいホルモンであるアディポ $\mathrm{Q}$ (ACRP30、アディポネクチンとも呼ばれる)(31)がある。また、

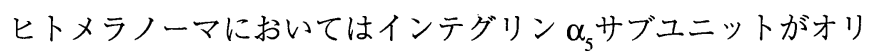
ゴシアル酸をもつ (32)。さらにごく最近、ヒトミルク CD36に 
number of glycoproteins in mammals have been shown to bear di/oligo/polysialic acid structures and several carrier glycoproteins were identified. In the brain, NCAM from adult (17), CD166 (29), and synaptophysin are disialic acid-containing glycoproteins. In serum, fetuin (30), $\alpha_{2}$-macroglobulin (30), and adipoQ (adiponectin, ACRP30) (31) a new adipocytokine, which controls the metabolism of lipids and is involved in arteriosclerosis and diabetes are disialic acid-containing glycoproteins. In human melanoma, $\alpha$-subunit of integrin is identified as an oligosialic acid-containing glycoprotein (32). Recently, we identified CD36 in human milk as a polysialic acid-containing glycoprotein (33). In sea urchin, $\alpha 2,9$-linked polysialic acid occurs in sperm flagellum(34). As shown here, identification of these di/oligo/ polysialoglycoprotein demonstrated the occurrence and diversity of oligo/polymeric structure of sialic acids (Table I).

\section{Newly Identified Glycoproteins Modified by the Di/Oligo/ Polymer of Sialic Acids}

C-1. Disialic Acid Residues on CD166 during Neurite OutGrowth (29) and T Cell Activation (35)

CD166 is a member of the immunoglobulin superfamily and mainly exists in neural cells. CD166 is known to be a cell adhesion molecule via homophilic interaction between CD166 and CD166 and heterophilic interaction between CD166 and CD6. We demonstrated that disialic acid residues are linked to the $O$-linked chain of CD166 and that ST8Sia III whose substrate is unknown would be an enzyme responsible for the production of disialic acid residues. Neuro2A cells differentiate into
ポリシアル酸構造の存在が明らかとなった (33)。また、ウニ精 子では $\alpha 2 \rightarrow 9$ 結合のポリシアル酸が鞭毛に発現していることを 証明した(34)。このように新しいポリシアル酸含有糖タンパク 質および数多くのジシアル酸、オリゴシアル酸含有糖タンパク 質の同定がなされたことによって、シアル酸重合体の遍在性と その鎖長多様性の存在がはっきりと証明されてきた(表 I)。

\section{C. 新規シアル酸重合体修飾糖タンパク質}

C-1. CD166 上に存在するジシアル酸構造と神経突起形成 (29) および T 細胞活性化 (35)

CD166 は免疫グロブリンスーパーファミリーの一種で、主 に神経細胞に存在する。CD166はホモフィリックな相互作用と CD6 などリリ゙ンドとのへテロフィリックな相互作用を介した 細胞接着に関わる分子として知られている。我々は、この分子 の $O$-型糖鎖上にジシアル酸が存在すること、このジシアル酸構 造の形成には、 $\alpha 2,8$-シアル酸転移酵素の中でも、これまであま りその働きが分かっていなかった ST8SiaIII が関与していること を証明した。特に興味深いのは、Neuro2A 神経芽腫細胞の例で ある。Neuro2A はレチノイン酸処理すると神経分化して突起形 成する細胞である。この細胞に、外から GD3 や GQ1c のような ガングリオシドを加えたり、ST8Sia I (GD3 合成酵素) の遺伝子 導入によって強制的にGD3を発現させたりすると、レチノイン 酸処理なしでも分化が開始されることから、神経突起形成にお ける GD3 などのガングリオシドの重要性が示されている。しか しながら、Neuro2A 細胞には、もともとジシアル酸構造をもつ ガングリオシドもその合成酵素も存在しない。また、我々は、

Table I. Di/oligo/polysialic acid-containing glycoconjugates identified so far.

\begin{tabular}{llll}
\hline Carrier molecule & Origin & DP & Ref. \\
\hline Glycocalyx & Neuroinvasive bacteria & $100-200$ & 7,8 \\
Neural cell adhesion & Vertebrate embryonic brain, & $2-50$ & 7,12 \\
molecule (NACM) & hippocampus, olfactory bulb & & \\
Polysialoglycoprotein (PSGP) & Salmonidae fish egg & $2-24$ & 11 \\
Sodium channel & Eel, Rat brain & $\geq 8$ & 10,58 \\
CD36 & Milk in mouse and human & $2-18$ & 33 \\
Integrin ( $\alpha_{5}$-subunit) & Human melanoma, fibroblast, leukemia cell & $5-7$ & 32 \\
Megalin & Rat kidney & $2-?$ & 59 \\
Ceruloplasmin & Various tissues in rat & $2-?$ & 60 \\
Ganglioside & Various tissues from deuterostome & $2-4$ & 61 \\
Sperm binding protein & Sea urchin egg & $2-3$ & 62 \\
Chromoglanin & Bovine medulla of suprarenal gland & 2 & 63 \\
Band-3 & Red blood cell from human & 2 & 64 \\
Glycophorin & Red blood cell from human & 2 & 65 \\
Synaptophysin & Mouse brain & 2 & 66,67 \\
Fetuin & Bovine serum & 2 & 30 \\
$\alpha_{2}$-Macroglobulin & Bovine serum & 2 & 30 \\
AdipoQ & Bovine serum, 3T3-L1 cell & 2 & 31 \\
CD166 & Mouse brain, Neuro2A, Mouse T cell & 2 & 29,35 \\
\hline
\end{tabular}


neurons under retinoic acid and neurites are formed. It was shown that GD3 is important for neural differentiation because Neuro2A cells can differentiate into neurons without retinoic acid after the addition of exogenous GD3 or GQ1c or forced expression of GD3 synthetase. However Neuro2A cells have neither GD3 nor GD3 synthetase. We also showed that retinoic acid did not induce the GD3 expression. We hypothesize that disialic acids are expressed on glycoproteins after the addition of retinoic acid and that the disialic acid on glycoproteins is the major player in neural differentiation like that on glycolipid. Actually, the expression of disialic acid on CD166 was at a low level before differentiation and the amounts of disialic acid residues increased after stimulation with retinoic acid. Furthermore, the disialic acid-specific antibody inhibited the neurite elongation. These results clearly showed that the disialic acid on CD166 is involved in neural differentiation (Fig.3).

Gangliosides are involved in the signal transduction pathway of $\mathrm{T}$ cell activation. It is known that $\mathrm{T}$ cell proliferation is induced by cross-linking of CD3/CD4 using the anti-CD3/CD4 antibody. Co-treatment of rat $\mathrm{T}$ cells with anti-ganglioside antibody ACl ( $\alpha 2 \rightarrow 8$-linked diNeu5Gc, see Table IV) and antiCD4 resulted in a marked stimulation of $\mathrm{T}$ cell proliferation, although boith these antibodies failed to activate the rat $\mathrm{T}$ cells (42). It is worthy of note here that the $\mathrm{ACl}$ epitope was the common epitope of a glycolipid (Neu5Gc)GD1c and the 100 $\mathrm{kDa}$ glycoprotein on rat $\mathrm{T}$ cells. Recently, we identified the 100 $\mathrm{kDa}$-glycoprotein as CD166 in mouse T cells. These results suggest a novel regulatory pathway of $\mathrm{T}$ cell activation involving CD4 and the diNeu5Gc glycotopes possibly on CD166 as well as glycolipids.
レチノイン酸で突起形成誘導しても、それらのガングリオシド 発現は誘導されないことをつきとめた。これらのことから、 我々は、レチノイン酸で突起形成誘導すると、ガングリオシド 上ではなく糖タンパク質上にジシアル酸構造が発現して、その ジシアル酸残基がガングリオシドと同等の機能を果たしている のではないかと考えた。実際に調べてみると、レチノイン酸処 理による分化の進行にともなって、もともと低レベルのジシア ル酸構造をもつCD166 上で、ジシアル酸構造の量が大幅に増加 することが見いだされた。また、ジシアル酸構造特異的な抗体 存在下で分化誘導すると、神経の突起伸長が抑制されることが わかった。以上のことから、CD166上のジシアル酸構造が神経 細胞の分化に関わっていることが示された (図 3)。

また、 $\mathrm{T}$ 細胞の活性化において、ガングリオシドがシグナ ル伝達経路に関与していることが知られている。T細胞の活性 化は $\mathrm{T}$ 細胞受容体を刺激することによって引き起こされ、in vitro では $\mathrm{T}$ 細胞受容体の一部である $\mathrm{CD} 3$ を抗体により架橋さ せると、特に CD4 抗体との共存下で架橋させると強く活性化さ れる。一方、ラット T 細胞を $\alpha 2 \rightarrow 8$ 結合 Neu5Gc のダイマー構 造に特異的な抗体 $\mathrm{AC} 1$ (糖脂質抗原で作製) と抗 CD4 抗体の共 存下で培養すると著しい活性化が起こることも知られている。 ラット $\mathrm{T}$ 細胞上には $\mathrm{AC} 1$ 反応性糖脂質 (Neu5Gc) GD1c が存在 することから、 T細胞活性化においてジシアル酸をもつガング リオシドの重要性が議論されてきた (42)。興味深いことは、 ラット T 細胞において、 $\mathrm{AC} 1$ エピトープは糖脂質上だけでなく $100 \mathrm{kDa}$ 糖タンパク質上にも存在する共通糖鎖抗原であるとい う点である。そして我々は、最近、マウスでこの $100 \mathrm{kDa}$ 糖夕 ンパク質がCD166であると同定した。すなわち、糖脂質だけで なく糖タンパク質 CD166 上に存在するジシアル酸構造が、CD4 と共同して T 細胞の活性化を調節する可能性を示唆しており、 その分子機構はきわめて興味深い。

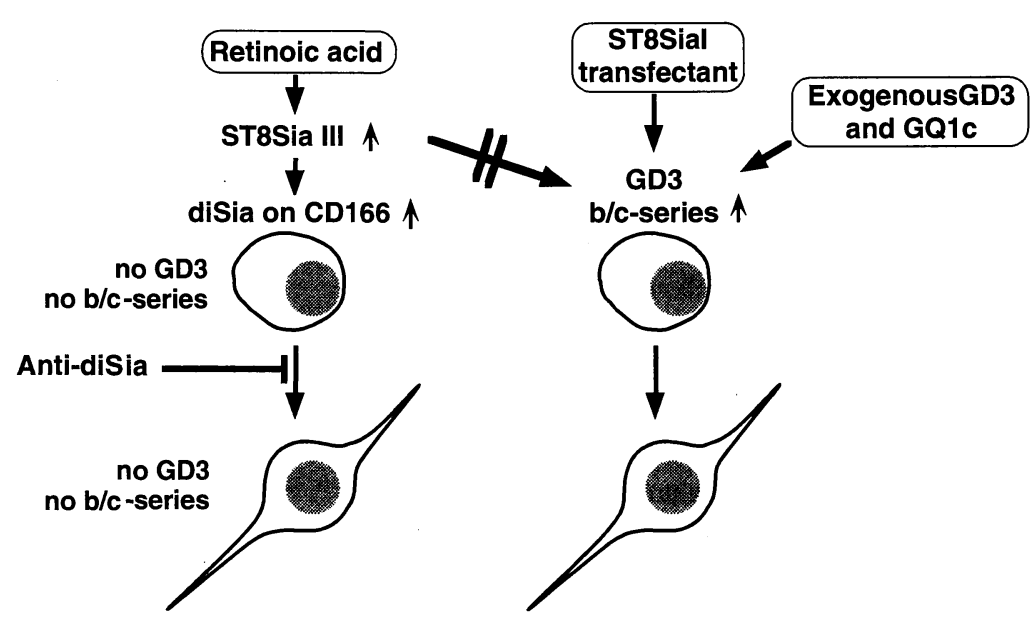

Fig. 3. $\alpha 2,8$-Linked disialic acid is involved in neurite outgrowth. Right: Forced expression of disialoganglioside (exogenous addition of GD3 and GQ1c or stable expression of GD3 synthetase (ST8Sia I)) induces neurite outgrowth in Neuro2A cell without retinoic acid. Left: Retinoic acid induces the expression of ST8Sia III in Neuro2A cell and the disialic acid residue on CD166 increases. However, the disialoganglioside is not expressed. The anti-disialic acid antibody inhibits the neurite outgrowth of Neuro2A cell. These results indicate that the disialic acid on CD166 is important in neurite formation in Neuro2A cell. 
Trends in Glycoscience and Glycotechnology Vol.16 No.91 (September 2004) pp.331-344

\section{C-2. Serum Glycoprotein}

Highly sensitive chemical methods allow us to search for di/oligosialic acid-containing glycoproteins in serum. We have recently demonstrated that fetuin, $\alpha_{2}$-macroglobulin $\left(\alpha_{2} M\right)$, and adipoQ from bovine serum are members of diSia-bearing glycoproteins $(30,31)$. However, these glycoproteins do not always contain disialic acid structures on the molecules, and $1 \%$ of fetuin, $4 \%$ of $\alpha_{2} \mathrm{M}$ and several $\%$ of adipoQ molecules were estimated to contain disialic acid structures. These results suggest that a small population of these glycoproteins is specifically terminated by the $\alpha 2 \rightarrow 8$-linked disialic acid glycotope depending on developmental and physiological changes. It should be noted here that $\alpha_{2} \mathrm{M}$ and adipoQ are known to change their levels in blood in response to inflammation and some hormones, respectively. Furthermore, most of the disialic acid-containing species of $\alpha_{2} \mathrm{M}$ appear to have a nick scission along the $170 \mathrm{kDa}-$ polypeptide chain to form $110 \mathrm{kDa}$ - and $60 \mathrm{kDa}$-polypeptide chains. Interestingly, this type of nick in $\alpha_{2} \mathrm{M}$ is usually formed when the $\alpha_{2} \mathrm{M}$ inhibits some protease activities, which may be induced in response to inflammation. Therefore, it can be speculated that diSia structures on the $\alpha_{2} \mathrm{M}$ may possibly have some role in inflammatory responses. In the same way, the disialic acid glycotope on fetuin and adipoQ may also modify physiological roles of these serum glycoproteins. AdipoQ in particular, is one of the cytokines secreted from adipose tissue and its receptor is a seven-times transmembrane-type receptor. The importance of the posttranslational modification of adipoQ is also pointed out because of the difference of biological effects between intact and recombinant adipoQ as is often the case with hormone-like molecules.

Recently, we have shown that a $32 \mathrm{kDa}$-glycoprotein is identified as an acute phase glycoprotein induced by the inflammation stimulated by LPS or turpentine oil (36). The expression of disialic acid-containing glycoprotein increased after the inflammation stimuli, indicating that the disialic acid on the 32 $\mathrm{kDa}$-glycoprotein may be involved in inflammation.

\section{C-3. Oligosialylation of the $\alpha 5$-Subunit of Integrin (32)}

Integrin is widely distributed as the receptor for fibronectin. Recently, it has been shown that the integrin on human melanoma cells, fibroblast cells and leukemia cells is oligosialylated. It was demonstrated that removal of the oligosialic acid from the integrin by linkage-specific sialidase digestions inhibited the adhesion toward fibronectin. Colominic acid (average DP $=15$ ) could not inhibit the integrin-fibronectin interaction. The binding of an antibody recognizing the fibronectin binding domain of the integrin was weakened after oligosialic acid depletion. These results indicate that oligosialic acid on integrin maintains the conformation in which fibronectin can bind strongly and promotes the adhesion to fibronectin. Notably, another group shows that the disialic acid residue on gangliosides (GT1b, GD3) interacts with high mannose-type $N$ -

\section{C-2. 血清糖タンパク質}

微量分析が可能となり、血清中のジシアル酸含有糖タンパ ク質を検索したところ、ウシ血清中でフェツイン、 $\alpha_{2}$ マクログ ロブリン $\left(\alpha_{2} \mathrm{M}\right) 、$ 小よ゙アディポ $\mathrm{Q}$ (アディポネクチン) がジシ アル酸含有糖タンパク質であることが明らかとなった (30、31)。 しかしながら、これらの分子が $100 \%$ \%ジアリル化修飾をうけ

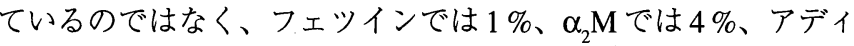
ポ $\mathrm{Q}$ の数\%がジシアリル化修飾を受けていた。これらの結果 は、発生段階や生理学的変化に呼応して、 $\alpha 2 \rightarrow 8$ 結合ジシアル 酸構造が結合した糖タンパク質が発現してくるため、ごく一部 の分子だけがジシアル酸を特異的に結合するようになるとも考 えられる。 $\alpha_{2} \mathrm{M}$ やディポ $\mathrm{Q}$ の血中レベルが、炎症時およびあ るホルモンの作用によって変化するという事実は注目に值す る。また、ジシアル酸構造をもつ $\alpha_{2} \mathrm{M}$ 糖タンパク質のほとんど は $170 \mathrm{kDa}$ ポリペプチド鎖に切断がおこり、110 kDa および 60 $\mathrm{kDa}$ のポリペプチド鎖を生じている。興味深いことに、 $\alpha_{2} \mathrm{M}$ の この種の切断は普通、炎症時などで誘起されるある種のプロテ アーゼ活性を $\alpha_{2} \mathrm{M}$ が抑える際に起こることが知られている。 そのため、 $\alpha_{2} \mathrm{M}$ 上のジシアル酸構造は炎症反応の際に $\alpha_{2} \mathrm{M}$ の機 能を制御する役割を果たしていることが考えられる。同様に、 フェツインやアディポ Qにおいても、ジシアル酸鎖が血清糖夕 ンパク質の生理学的役割を修飾しているかも知れない。特にア ディポ Q は脂肪細胞が分泌するアディポサイトカインといわれ るホルモンの一種であり、近年 7 回膜貫通型の受容体が明らか にされてきたが、組換え体とインタクトな分子での作用が完全 には一致しないことから、翻訳後修飾されることの重要性が示 されている。

近年、ジシアル酸の炎症における役割を調べる目的で、マ ウスにLPS やテレビン油刺激で炎症を誘発したところ、血清中 のジシアル酸含有糖タンパク質である $32 \mathrm{kDa}$-糖タンパク質上が 急性期タンパク質として同定された (36)。ジシアル酸修飾をう けた糖タンパク質が発現上昇するということは、炎症時におけ る生理機構に関わっていることを示唆しており興味深い。

C-3. インテグリン $\alpha 5$ サブユニットのオリゴシァル酸修飾 (32)

インテグリンはフィブロネクチン受容体として広く生体内 に存在している。近年、ヒトメラノーマ細胞、線維芽細胞、白 血病細胞上のインテグリン $\alpha 5$ サブユニットが重合度 5 7 のオ リゴシアリル化を受けていることが明らかになった。インテグ リン $\alpha 5$ に存在するオリゴシアル酸のフィブロネクチンへの接 着への関わりは、結合特異的なシアリダーゼ消化によるフィブ ロネクチンセファロースによるプルダウン法によって行われ、 オリゴシアル酸が除去されることにより接着が阻害される事が 分かった。また、オリゴシアル酸のフィブロネクチンへの接着 の機序に関しては、シアル酸の重合体(平均重合 15) であるコロ ミン酸によって阻害がかからないこと、 $\alpha 5$ 上のフィブロネクチ ンとの接着に関わる領域をエピトープにする抗体は、オリゴシ アル酸の除去により $\alpha 5$ との反応性が低下したことから、オリ 
linked glycan chains on the $\alpha$-subunit of integrin and regulates the adhesion to fibronectin. Thus, the di/oligosialic acid residues are important in the interaction between integrin and extracellular matrix.

\section{C-4. Polysialylation of CD36 in Human Milk (33)}

Milk is very important for a mammalian newborn baby because milk is the only source of nutrition and it plays a central role in protection from infection via trapping the bacteria from the environment. Milk is the perfect food that contains various nutritious and immunity-related molecules. Milk attracts many researchers because of its multifunctional aspects including nutrition and protection. On the other hand, little attention has been paid to the significance of sialic acid in milk, although there are some interesting observations: Sialic acids are rich in colostrum (38); The amount of gangliosides in the brain of sialic acid-fed rats increased and the learning ability of the rats improved as compared with rats fed on a sialic acid-free diet $(39,40)$.

Using the sensitive chemical methods (described above), we first detected polysialic acid in human milk. The chain length of the polysialic acid residues was of at least 18 sialic acid residues (Fig.4). The polysialic acid-containing glycoprotein was identified as CD36. Polysialic acid was linked to the $O$-linked glycan chain(s). Not all CD36 molecules were polysialylated, but $5 \%$ of CD36 was modified by this unique sugar chain. The developmental profile of the polysialylated CD36 expression shows that the level of polysialic acid on CD36 in milk reaches its maximum at 1-month post-parturition, decreases to that in the colostrum, and later remains unchanged for 6 months (Fig. 4). Not only human milk but also mouse milk contains
ゴシアル酸の存在により、 $\alpha 5$ はフィブロネクチンにより強く親 和性を示すような高次構造を維持することが可能となり、その 結果、インテグリン $\alpha 5 \beta 1$ のフィブロネクチンへの接着が促進 されることが考えられている。また、これとは別に、ジシアリ ルガングリオシド (GT1bとGD3) は $\alpha 5$ サブユニットのハイマン ノース糖鎖と相互作用し、上皮細胞とフィブロネクチンの相互 作用を調節している可能性も示されている (37)。このように、 細胞と細胞外マトリックスとのインテグリンを介した相互作用 にもジ・オリゴシアル酸が密接に関わっているのである。

\section{C-4. ヒトミルク CD36 のポリシァル酸修飾 (33)}

哺乳動物の新生児にとって、ミルクは唯一の栄養源である こと、免疫系が完成されていない新生児において、外界からの 病原体を捕捉するという感染防御の役割を果たすことから非常 に重要なものである。このようにミルクは、様々な分子が巧み に調合されている完全食品である。その中でも、ミルクオリゴ 糖は栄養源と感染防御の両方の役割をもつ多機能分子であり、

盛んに研究されている。一方、ミルク中に含まれるシアル酸に 関しては、初乳に非常に多く含まれていること (38) や、シアル 酸を投与したラットでは、脳でのガングリオシド量が増加し、 投与していないラットと比べて学習機能が向上した $(39,40)$ と いう報告もあるが、シアル酸の機能に関しては不明な点が多 w。

そこで近年開発された微量分析法により、ミルク中のシア ル酸の重合度を分析したところ、重合度 18 までのシアル酸重合 体が検出された。この担体タンパク質を同定したところ、CD36 であることが判明した (図 4)。ポリシアル酸は CD36 の O-型糖 鎖上に結合している。すべての CD36がポリシアル酸修飾を受
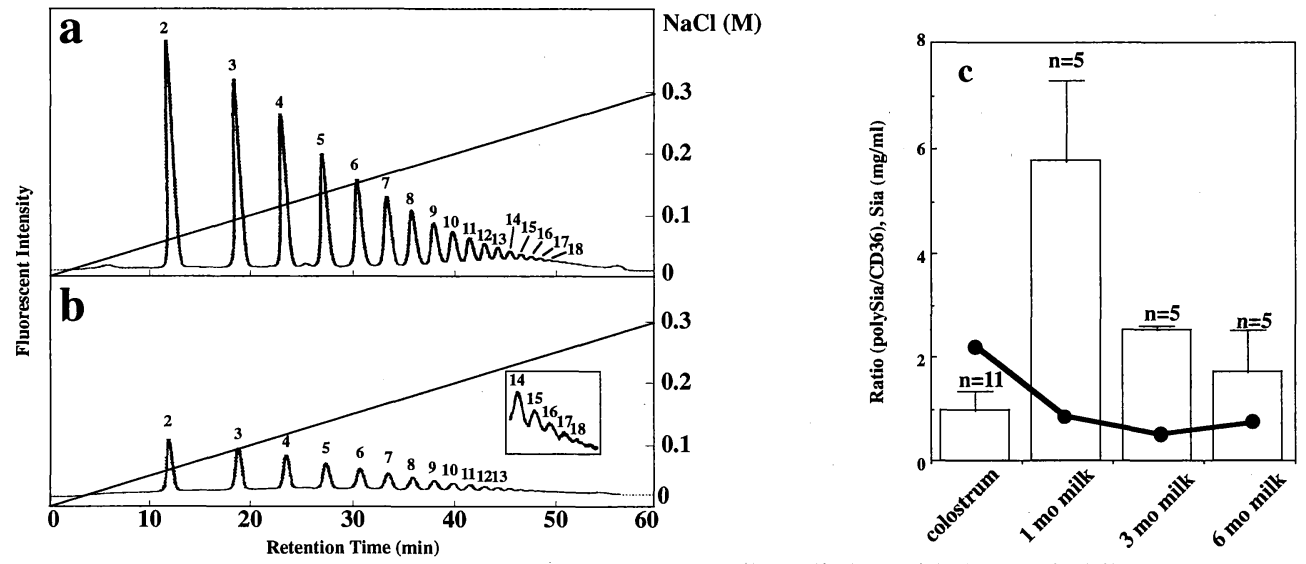

Fig. 4. $\alpha 2,8$-Linked polysialic acid in human milk. Fluorometric anion-exchange HPLC profiles of (a) authentic DMBlabeled $\alpha 2,8$-linked oligo/polysialic acid chains and (b) free oligo/polysialic acid chains derived from mild acid hydrolysate of human milk, followed by labeling with DMB. The fluorometric anion-exchange chromatography was performed with a linear gradient of $0-0.3 \mathrm{M} \mathrm{NaCl}$ and monitored on a fluorescence detector (set at wavelength of $373 \mathrm{~nm}$ excitation and $448 \mathrm{~nm}$ emission). The number on the peak indicates the DP. (c) Developmental changes of sialic acid content in milk (O) and the polysialic acid on CD36 $(\square)$ in colostrum and milk of up to 6 months after parturition. $\mathrm{N}$ indicates the number of samples. 
polysialylated CD36.

CD36 is one of the scavenger receptors and expressed on the platelets, macrophage, and milk. The multiple functions of CD36 are known. For example, CD36 activates platelets when collagen and thrombospondin bind to CD36. Binding of acidic phospholipids to CD36 triggers the removal of apoptotic cells. CD36 is involved in the removal of oxidized LDL and glycated proteins from serum by trapping them. It is also shown to be involved in the transport of fatty acids (40). CD36-knock out mice exhibit no obvious phenotypes, and the function of CD36 in milk is still unknown. An interesting observation about a function of the carbohydrate part of CD36 was made, showing that $\mathrm{N}$-linked carbohydrate chains altered the binding ability of CD36 to fatty acids (41). Our original finding that $O$-linked carbohydrate chains are modified by the unique polysialic acid residues implicates a new function of CD36 in milk. For example, it can be speculated that DP of di/oligo/polysialic acid chains regulates the binding ability of CD36 toward various molecules described above. It was previously reported that sialic acids were most enriched in colostrum. However, we demonstrated that the expression of polysialic acid residues on the milk CD36 was transiently up-regulated at 1 month post-parturition. As the milk consists of the components which help a baby to grow, the polysialic acid residue might be the (carbohydrate) material which is used for the construction of the neural system. It would be interesting to reveal a new function of polysialic acid other than its anti-adhesive character.

\section{C-5. Discovery of a New Type of Polysialic Acid in Sea Ur- chin Sperm Flagellum (34)}

Lipid rafts are a hot spot for signal transduction. Based on our own finding described below, we are considering that rafts are also a hot spot for the presentation and functioning of the rafts-localized glycotope on glycoproteins and glycolipids. We demonstrated that the rafts are enriched in the glycotopes that are shared by both glycolipids and glycoproteins. We have been focusing on the raft-mediated interactions in sea urchin fertilization as a microscopic model of sperm and egg interactions. In sea urchin sperm, we developed monoclonal antibodies against glycolipids localized in the rafts and one of them exhibited immunospecificity to $\mathrm{HSO}_{3} \rightarrow 8 \mathrm{Neu} 5 \mathrm{Ac}$ structure $\left(\mathrm{HSO}_{3} \rightarrow 8 \mathrm{Neu} 5 \mathrm{Ac}\right.$ ). This glycotope exists not only in glycolipids but also in glycoproteins. The non-reducing terminal end of the $40-80 \mathrm{kDa}$-glycoprotein, a major sialoglycoprotein in sperm, was capped by the $\mathrm{HSO}_{3} \rightarrow 8 \mathrm{Neu} 5 \mathrm{Ac}$ residue. Interestingly, the internal sialyl chain consists of a new type of polysialic acid, i.e., a polymer of $\alpha 2,9-$ linked Neu5Ac (Fig. 5). This new type of polysialic acid structure was unequivocally determined by the chemical methods (mild/hydrolysis-fluorometric HPLC (Fig. 5), fluorometric $\mathrm{C}_{7} / \mathrm{C}_{9}$ analysis, methylation analysis, and GCMS) attentively. This structure is exclusively localized on the flagellum. It is interesting to note that the $\alpha 2,9$-linked Neu5Ac-
けているわけではなく、ごく一部 ( $5 \%$ 程度) の分子が修飾さ れている。また、このポリシアル酸構造は、泌乳期が始まって から 1 ケ月後にピーク量を迎え、その後、初乳と同レベルまで 減少し、そして、6ヶ月間一定になるという分化段階特異的な 発現をしている(図 4)。さらに、ヒトだけではなく、マウスミ ルク CD36もポリシアル酸修飾を受けていることも判明した。

CD36 はスカベンジャーレセプターの一種で、血小板、マク ロファージ、ミルクに存在することが知られている。機能は多 岐にわたっており、コラーゲンやトロンボスポンジンの受容体 として働いて、血小板の活性化を引き起こしたり、酸性りン脂 質に結合して、アポトーシスを起こした細胞を除去したり、酸 化 LDL や糖化タンパク質に結合して、血中からそれらを除去す る作用がある。また、長鎖脂肪酸の輸送に関わることも明らか にされている (40)。ノックアウトマウスの解析も進められてい るが、ミルク中の CD36の機能については、ほとんどわかって いない。特にCD36の糖鎖の機能に関しては、脂肪酸との結合 性にそれ自身の $N$-型糖鎖の存在が重要であることが示唆されて いるにとどまっている (41)。CD36の $O$-型糖鎖上にポリシアリ ル基が発見されたことは、CD36の新機能 (特にミルク中での)の 発見に繋がるものと期待される。例えば上述の特にCD36の 様々な分子に対する接着活性が、シアル酸の重合度の違いで厳 密に制御される可能性を追求することは興味深い。また、初乳 にはシアル酸が多量に含まれていることは知られていたが、そ の重合体であるポリシアル酸は泌乳期開始の 1 ケ月後に一過的 に増加するという現象が初めて明らかになった。ミルクには新 生児の免疫学的、栄養学的な見地だけでなく、その成長を支え る材料成分が備わっていることを考えると、ポリシアル酸が新 生児における神経系構築のための材料 (糖鎖) 源として機能して いる可能性もある。ポリシアル酸のミルクにおける機能を探る 中で、反接着作用以外の新機能が見いだされることが期待され る。

\section{C-5. ウ二精子鞭毛における新規ポリシアル酸修飾の発見 (34)}

我々は、糖タンパク質と糖脂質の共通糖鎖エピトープの存 在とその機能発現の場としてのラフトの役割に注目している。 そのモデルケースとしてウニの受精に扔ける精子と卵の相互作 用の研究を行っている。我々はこれまでに、ウ二精子上のラフ 卜成分に含まれる糖脂質の解析を行う過程で、 $\mathrm{HSO}_{3} \rightarrow 8 \mathrm{Neu} 5 \mathrm{Ac}$ 構造に対する抗体を作成し、それを用いて検索したところ、こ の構造が糖脂質のみならず、ラフト上の糖タンパク質上にも存 在することをつきとめた。そしてその主な担体タンパク質が 40 $\sim 80 \mathrm{kDa}$ の未同定のムチン様糖タンパク質上に存在することを 明らかにした。この 40〜80 kDa 糖タンパク質において、ポリシ アル酸構造は $O$-型糖鎖上存在しており、その非還元末端は硫酸 化シアル酸によってキャップされている。この新規ポリシアル 酸構造 (図 5) は詳細な化学的分析 (緩和酸加水分解/蛍光 HPLC 分析 (図 5)、蛍光 $\mathrm{C}_{7} / \mathrm{C}_{9}$ HPLC 分析、メチル化分析、GC-MS) に よって厳密な、 $\alpha 2 \rightarrow 9$ 結合であることが証明された。この糖夕 


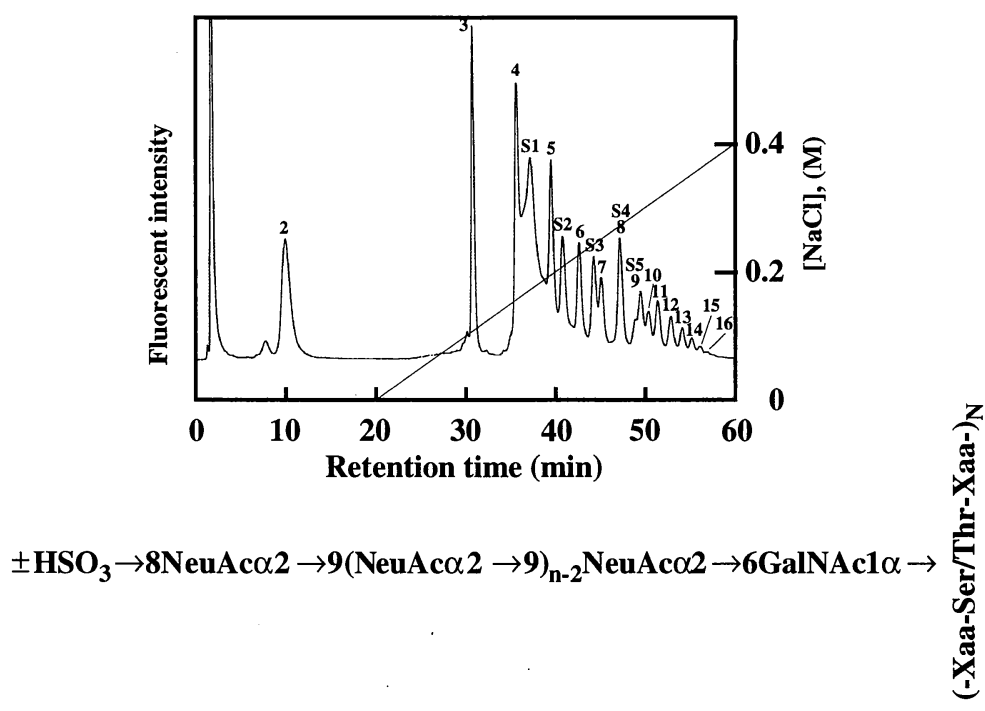

Fig. 5. Sulfated $\alpha 2,9$-linked polysialic acid in sea urchin sperm. Upper, HPLC of DMB-derivatives of the mild acid hydrolysate of sea urchin sperm glycopeptides. The hydrolysate was derivatized with DMB and applied to an anion-exchange HPLC with a gradient from 0-0.4 M NaCl (straight line). The elution profile was monitored on a fluorescence detector (set at wavelength of $373 \mathrm{~nm}$ excitation and $448 \mathrm{~nm}$ emission). Bottom, A proposed structure of the $O$-linked glycan chains of sea urchin sperm. n, on average 15; N, 4-5; Xaa, unidentified amino acid.

bearing molecule and the $\alpha 2,8$-linked Neu5Ac-bearing molecule is co-localized in the same rafts. It is also suggestive of biological functions that the polysialic acid potentially possesses $\mathrm{Ca}$ binding ability and anti-adhesive effect, and these properties are greatly strengthened by the clustered structure along the mucintype $40-80 \mathrm{kDa}$ glycoprotein, which is also localized in the rafts in cluster. Studies on the biological functions of the $\alpha 2,9$ polysialic acid and the $\mathrm{HSO}_{3} \rightarrow 8 \mathrm{Neu} 5 \mathrm{Ac}$ epitopes are underway in our laboratory.

\section{C-6. $\alpha 2 \rightarrow$ 9-Linked Polysialic Acid on Mouse Neuroblastoma Cell Lines}

In 1985, Fukuda et al. showed the Neu5Aco2,9Neu5Ac structure on the lactosaminoglycan in human teratocarcinoma cells (PA1) by the methylation analysis and FAB-MS (43). Recently, Inoue et al. showed the $\alpha 2,9$-linked polysialic acid in C1300 mouse neuroblastoma cells (NB41A3) by the mild acid hydrolysis/fluorometric HPLC analysis and fluorometric $\mathrm{C}_{7} / \mathrm{C}_{9}$ analysis (44). Identification of carrier protein and functional analyses are interesting subjects to be solved.

\section{Sialyltransferases Responsible for the Biosynthesis of Di/ Oligo/Polysialic Acids}

Since the expression of $\alpha 2,8$-linked di/oligosialic acid on glycoproteins is glycoprotein species-specific, cell-type- and tissue-type-specific, developmental stage-dependent, and differentiation-associated, the biosynthesis of these sialyl glycotopes must be strictly regulated. Sialyltransferases are the enzymes that transfer sialic acid to the glycoconjugates. Linkage-specific sialyltransferases are localized in the Golgi apparatus and use CMP-Sia as a donor substrate. Sialyltransferases responsible for
ンパク質は精子の頭部ではなく、鞭毛部に局在していることが わかった。ガングリオシドと共通な末端部分 (硫酸化シアル酸) を持つこと、ポテンシャルにカルシウム結合能をもち、かつ反 接着作用をもつポリシアル酸が一つの糖の鎖に組み込まれ、そ の分子がムチン様糖タンパク質上でクラスター化しているこ と、さらにラフトという部位に同居して局在することから、ラ フト機能の制御的役割を果たすものと考えられる。 $\alpha 2,9$-結合ポ リシアル酸と $\mathrm{HSO}_{3} \rightarrow 8 \mathrm{Neu} 5 \mathrm{Ac}$ エピトープの生物学的機能の解 析は、現在我々のグループで進めている。

C-6. マウス培養細胞上の $\alpha 2 \rightarrow 9$ 結合ポリシアル酸構造

1985 年に、福田らはヒトテラトカルシノーマ細胞 (PA1) 上 のラクトサミノグリカンには、Neu5Aco2,9Neu5Ac ジシアル酸 構造が存在していることを、メチル化分析、FAB/MS 分析によ り証明した (43)。その後、井上らは C-1300 マウスニューロブラ ストーマ細胞 (NB41A3) 上に、 $\alpha 2,9$-結合ポリシアル酸構造を緩 和酸加水分解/蛍光 HPLC 分析、蛍光 $\mathrm{C}_{7} / \mathrm{C}_{9}$ HPLC 分析法により 検出した (44)。今後、 $\alpha 2 \rightarrow 9$ 結合ポリシアル酸構造をもつ担体 分子の同定および生物学的機能の解明が待たれる。

\section{D. シアル酸重合体を生合成する糖転移酵素}

糖タンパク質上の $\alpha 2 \rightarrow 8$ 結合シアル酸重合体の発現は糖夕 ンパク質の分子種に特異的であり、細胞種や組織、発生段階あ るいは分化過程に特異的であり、これらのシアロ糖鎖エピトー プの生合成は厳密に制御されている。複合糖質上へのシアル酸 の転移は、一般的にシアル酸転移酵素によって担われている。 ゴルジ装置に存在する結合様式特異的なシアル酸転移酵素は、 シアル酸供与体であるCMP-シアル酸を用いて、シアロ複合糖質 を生合成する。これまでクローニングされてきた $\alpha 2,8$-結合シア 
the biosynthesis of $\alpha 2,8$-linked sialic acid residues consist of six members, ST8Sia I-ST8Sia VI, as far as clones until now $(45,46)$. ST8Sia I and ST8Sia V are enzymes responsible for the biosynthesis of gangliosides. ST8Sia II (STX) and ST8Sia IV(PST) are known to be involved in the biosynthesis of the polysialic acid ( $\mathrm{DP}=$ up to 50 ) at least in vitro. These enzymes appear to be more specific to NCAM and polysialoglycoprotein (PSGP) in fish egg $(46,47)$ than any other glycoproteins tested so far. The deletion experiment of polysialic acid chain by Endo$\mathrm{N}$ digestion and the masking experiment by anti-polysialic acid antibodies would demonstrate the function of polysialic acid chain indirectly. Recently, knock-out and knock-down experiments of the enzyme genes which are responsible for the biosynthesis of polysialic acid or carrier protein bearing the polysialic acid chain have given legible results on the function of polysialic acid residue. Very recently, mice lacking in the ST8Sia IV gene decreased the expression of polysialic acid in specific brain regions and are impaired in LTD and LTP in the hippocampus CA1 region (48). However, no decrease in CA3 LTP was observed unlike the NCAM-deficient mice (48). On the other hand, mice lacking in the ST8Sia II gene did not exhibit impairment of the hippocampus synaptic plasticity, but instead resulted in the misguidance of infrapyramidal mossy fibers and the formation of ectopic synapses in the hippocampus (49). The ST8Sia II-deficient mice exhibited higher exploratory drive and reduced behavioral responses (49). ST8Sia II and ST8Sia IV are expressed in different special and temporal pattern among neural tissues and mice deficient in either ST8Sia II or ST8Sia IV showed different phenotypes. These results indicate that each enzyme is able to synthesize the polysialic acid chain, but plays different roles in brain. Studies on mice of double knock-out of ST8Sia II and ST8Sia IV would be informative.

ST8Sia III (50) and ST8Sia VI (51) can form short sialyl di/oligomer. Little is known about the acceptor glycoproteins of these structure in nature and the mechanism for stopping or continuing the synthesis of the dimer. ST8Sia III has the ability to synthesize the disialic acid from monosialylated glycoproteins and glycolipids (50), and might be important in the formation of the common disialic acid glycotope on glycoproteins and glycolipids. ST8Sia VI is shown to synthesize the disialic acid structure on $O$-linked glycan chains in glycoproteins (51).

\section{E. Di/oligosialic Acid-Binding Molecules}

It is well known that many bacteria and viruses have hemaggulutinins and some of them recognize the sialic acid residues on host cells (52). Recently, it has been shown that sialic acid-recognizing molecules are present on animal cells and consist of a lectin family, sialic acid-binding-immunoglobulin like lectin (siglecs) (5). Siglecs 1 to 11 and a siglec-like molecule (siglec 12) have been cloned. Siglec is the type-I membrane protein present on blood and neural cells. Siglec consists of a V-
ル酸構造を生合成するシアル酸転移酵素は ST8Sia I ST8SiaVI の 6 種類である $(45 、 46)$ 。その中で、ST8Sia I と ST8SiaV は糖 脂質の生合成に関わっている。また、ST8Sia II (STX) と ST8Sia IV (PST) は in vitro で重合度 50 程度のポリシアル酸を生合成す ることがわかっており、NCAM と魚卵に存在するポリシアル酸

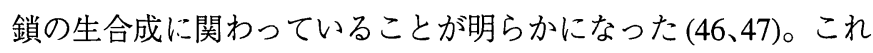
までポリシアル酸の機能解析には、細胞表面上のポリシアル酸 構造を䤃素により特異的に除去する方法 (Endo-N)、特異的抗体 でエピトープをブロックする方法を用いていたが、近年では、 酵素や担体分子遺伝子発現などのノックアウトやノックダウン の手法を用いることにより、直接的に機能を明らかにすること が可能になってきている。ポリシアル酸の機能を直接的に探る ために、ポリシアル酸転移酵素のノックアウトマウスが作製さ れている。ST8Sia IV ノックアウトマウスでは、脳の広範囲な領 域で、ポリシアル酸の発現量が減少し、海馬 CA1 領域では LTP やLTD の減少が見られるが、NCAMノックアウトマウスで見 られるCA3 領域での LTP の減少は観察されなかった (48)。ま た ST8Sia II 遺伝子のノックアウトマウスでは、海馬のシナプス の可塑性に変化はなかったが、錐体苔状繊維の誤った誘導によ り、海馬に異所シナプスが形成されていた。またこのマウスは 冒険心が旺盛で、恐怖心が減少していた (49)。ST8SiaIVと ST8Sia II はその発現場所や発現時期が異なること、またノック アウトマウスの表現系が異なることからも、同じポリシアル酸 を合成する酵素でも、担っている役割が異なることが明らかに なった。今後、ポリシアル酸の機能をより明確にするためには 方法の一つとして、ST8SiaIV と ST8SiaII のダブルノックアウト マウスの解析は興味深い。

ST8Sia III (50) と ST8Sia VI (51) は、短いシアル酸重合体を 形成する。基質となる糖タンパク質の同定や重合体形成のメカ ニズムはほとんど解析されていない。特に、ST8SiaIII は、糖夕 ンパク質糖鎖も、糖脂質糖鎖もジ・オリゴシアリル化すること ができる (50) ため、ガングリオシドと糖タンパク質上の共通糖 鎖エピトープを考える上でも、重要な役割を果たすことが考え られる。また ST8Sia VI は $O$ 型糖鎖上のジシアル酸構造の生合 成を担っていることが示されている (51)。

\section{E. シアル酸重合体結合分子}

多くのバクテリアやウイルスでは、その上にあるへマグル チニンなどが宿主のシアル酸残基を介して結合することがよく 知られている (52)。しかし近年、動物細胞上にもシアル酸を認 識する分子が存在し、一群のレクチンファミリーを形成してい ることが明らかにされている(5)。シアル酸結合免疫グロブリン 様レクチン (シグレック) と呼ばれる分子である。これまでに、 シアル酸結合能をもつシグレック 1 からシグレック 11 までの 
domain, responsible for the sialic acid binding, 1 to 16 repeats of the $\mathrm{C} 2$-domain (the number is different among siglecs), and a cytosolic domain. Most siglecs have ITIM motifs (inhibitory motif) and they are considered to play regulatory roles in signal transduction on the sialic acid binding. Please refer to an outstanding review in this issue. In this review, I just describe the specificity on the sialic acid binding. Siglecs mostly bind to the $\alpha 2,3-$ or $\alpha 2,6$-monosialyl residue, however, siglec $1,5,7,10$ and 11 show the affinity toward the $\alpha 2,8$-linkage (53). Siglec 7 (54-56) and siglec 11 (57) in particular have the ability to bind to the $\alpha 2,8$-linkages with high affinity. Although it is considered that natural ligand of siglecs that recognizes the disialic acid is gangliosides such as GD3, the di/oligosialic acid-containing glycoproteins described in this review might be candidates for natural ligands.

\section{Conclusion and perspective}

Many glycoproteins have now been demonstrated to contain di/oligo/polysialic acid structures and the functional implication of these glycotopes during fertilization, embryogenesis, differentiation, neurogenesis, inflammation, and immune response has been gradually revealed. Fig. 6 shows the world of sialoglycoconjugates viewed in terms of the chain length of sialic acid residues. Various aspects related with the di/oligo/polysialic acid world including structures of carbohydrates and carrier proteins, biosynthesis, recognition molecules have been well studied, but still more effort will have to be made before understanding the biological functions of these unique glycan struc-
分子とシグレック 12 というシグレック様分子がクローニングさ れている。シグレックは主に血球細胞や神経細胞に存在する夕 イプI膜糖タンパク質で、シアル酸に結合する Vドメインと、 シグレック間で長さが異なる 1 16 個の C2 ドメインおよび細 胞内ドメインからなる。ほとんどのシグレックの細胞内には ITIM (免疫レセプターチロシン依存性抑制性モチーフ) が存在し ており、シアル酸リガンドとの結合により、細胞内へのシグナ ル伝達を制御していると考えられている。詳細は Crocker 博士 らの総説を参照していただきたい。その中で特筆するべき点 は、シグレックのシアル酸の結合様式に対する特異性について である。シグレックのほとんどは非還元末端にシアル酸が $\alpha 2,3$ または $\alpha 2,6$ で結合した構造を認識するが、シグレック $1,5,7$, 10,11 のように $\alpha 2,8$ 結合シアル酸に親和性を持つものがあるこ とが明らかになってきた(53)。特に合成化合物などを用いた解 析からシグレック 7 (54-56)や 11 (57) はジシアル酸構造と強く 結合することが明らかにされている。シアル酸ダイマーを認識 するシグレックのリガンドは、ジシアロガングリオシドと考え られているが、本稿でも示したように、我々が見いだしている 種々のジシアル酸やオリゴシアル酸をもつ糖タンパク質分子が リガンドとなる可能性は高く、その検証は重要な課題である。

\section{おわりに}

糖タンパク質上のジ・オリゴ・ポリシアル酸糖鎖の存在が 証明され、受精、発生、分化、神経形成、炎症、免疫の諸現象 に関与することが示唆されてきている。これらの糖鎖の生物学 的重要性がさらに解明されるためには、精密な糖鎖構造解析と その担体タンパク質の同定、ジ・オリゴ・ポリシアル酸構造の

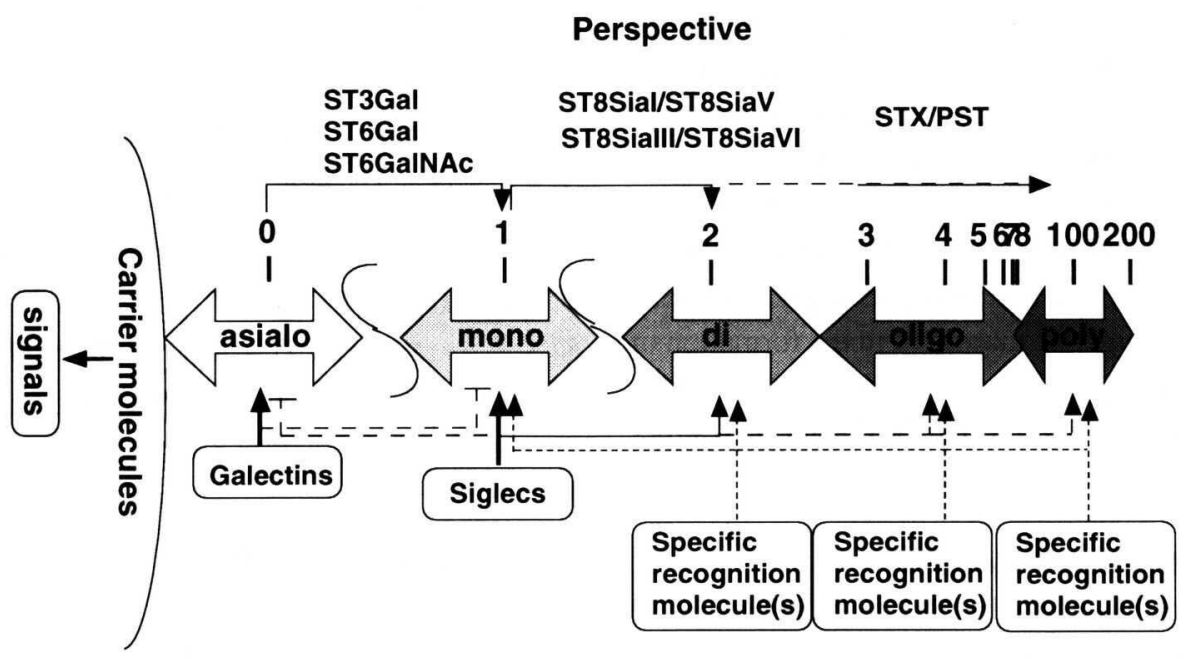

Fig. 6. The world of di/oligo/polysialic acid-containing glycoconjugates. Next to the large asialo- and monosialoglycoonjugate worlds, di/oligo/polysialo-glycoconjugate worlds extend. Sialyltransferases responsible for the biosynthesis of mono/di/oligo/polysialic acid residues are aligned at the top of the panel. Molecules involved in specific recognition of the asialo/mono/di/oligo/polysialic acid residues are aligned at the bottom of the panel. To understand this world more clearly, structural elucidation of carbohydrate and carrier parts of the glycoconjugates, searching for the specific recognition molecules and elucidation of the recognition mechanism, investigation of biosynthetic mechanism, and finally understanding of biological functions need to be done. 
tures. The first thing is to elucidate structures of glycan chains containing these glycotopes and identification of the carrier proteins. The second thing is to demonstrate the presence of molecules that specifically recognize and bind to the di/oligo/ polysialic acid glycotopes. More importantly, such "di/oligo/ polysialic acid recognition proteins" should be searched for and identified in the context of biological phenomena. The binding mechanism is also to be elucidated. The third thing is to investigate the mechanism that signals from the outside through the binding between di/oligo/polysialic acid chains and its binding counterpart enter the inside. Advanced research on the di/oligo/ polysialic acid chain will also give a clear answer why a cell has to decrease valuable energy by forming various di/oligo/ polysialic acid chains by several sialyltransferases. Furthermore, once we understand how the degree of polymerization of $\mathrm{di}$ / oligo/polysialic acid chains controls the function of the glycoproteins, an easy extension of the use of these attractive molecules to the glycotechnological field would be promising.

Studies described in this review by the author are supported in part by the Mizutani Foundation.
認識分子や結合分子の検索と結合様式の解明、およびそれらの 相互作用が細胞内へと伝わる機構を明らかにする必要がある (図 6)。今後、シアル酸重合体の研究がさらにすすめば、何故細胞 はシアル酸をモノシアル酸としてだけではなく、幾つもの酵素 を用意し、貴重なエネルギーを用いて、多様なシアル酸の重合 体を形成する必然性があったのかという問いの答えを得ること ができるであろう。そして、「シアル酸の重合度が精緻に制御 されることによって糖タンパク質の機能が制御される」とい う、新たな糖タンパク質機能調節メカニズムが明らかになれ ば、「シアル酸の重合度を人為的に制御することによって、あ る生理活性分子の機能をコントロールできる」可能性を示唆し ており、糖鎖工学的見地からも魅力的な分子となろう。

本稿で紹介した筆者の研究の一部は (財) 水谷糖質科学振興 財団の助成を受けている。

\section{References}

1. Schauer, R., Kelm, S., Reuter, G., Roggentin, P., and Shaw, L. (1996) in Biology of the Sialic Acids (Rosenberg, A., ed.) pp.7-67, Plenum Press, New York and London

2. Angata, T., and Varki, A. (2002) Chem. Rev. 102, 439-469

3. Shauer, R. (2004) Zoology 107, 49-64

4. Crocker, P. R., Kelm, S., Dubois, C., Martin, B., McWilliam, A. S., Shotton, D. M., Paulson, J. C., and Gordon, S. (1991) EMBO J. 10, 16611669

5. Crocker, P. R. (2002) Curr. Opin. Struct. Biol. 12, 609-615

6. Schwarzkopf, M., Knobeloch, K. P., Rohde, E., Hinderlich, S., Wiechens, N., Lucka, L., Horak, I., Reutter, W., and Horstkorte, R. (2002) Proc. Natl. Acad. Sci. U S A 99, 5267-5270

7. Troy, F. A. II (1996) in Biology of the Sialic Acids (Rosenberg, A., ed.) pp.95-144, Plenum Press, New York and London

8. Robbins, J. B., McCracken, G. H., Gotschlich, E. C., Ørskov, F., Ørskov, I., and Hanson, L. A. (1974) N. Engl. J. Med. 290, 1216-1220

9. Finne, J. (1982) J. Biol. Chem. 257, 11966-11970

10. James, W. M., and Agnew, W. S. (1987) Biochem. Biophys. Res. Commun. 148, 817-826

11. Inoue, S., and Iwasaki, M. (1978) Biochem. Biophys. Res. Commun. 93, 162-165

12. Bruses, J. L., and Rutishauser, U.(2002) Biochimie 83, 635-643

13. Fukuda M.(1996) Cancer Res. 56, 2237-2244

14. Sato, C., Inoue, S., Matsuda, T., and Kitajima, K. (1998) Anal. Biochem. 261, 191-197

15. Sato, C., Inoue, S., Matsuda, T., and Kitajima, K. (1999) Anal. Biochem. 266, 102-109

16. Sato, C., and Kitajima K. (1999) Trends Glycosci. Glycotechnol. 11, 371-390

17. Sato, C., Fukuoka, H., Ohta, K., Matsuda, T. Koshino, R., Kobayashi, K., Troy F. A. II, and Kitajima K. (2000) J. Biol. Chem. 275, 1542215431

18. Finne, J., Krusius, T., Rauvala, H., and Hemminki, K. (1977) Eur. J. Biochem. 77, 319-323

19. Michon, F., Brisson, J. R., and Jennings, H. J. (1987) Biochemistry 26, 8399-8405

20. Kitazume, S., Kitajima, K., Inoue, S., and Inoue, Y. (1992) Anal. Biochem. 202, 25-34

21. Rohr, T. E., and Troy, F. A. (1980) J. Biol. Chem. 255, 2332-2342

22. Nakamura, M., Hara, S., Yamaguchi, M., Takemori, Y., and Ohkura, Y. (1987) Chem. Parma. Bull. 35, 687-692

23. Hara, S., Takemori, Y., Yamaguchi, M., Nakamura, M., and Ohkura, Y. (1987) Anal. Biochem. 164, 138-145

24 . Sato, C., Kitajima, K., Inoue, S., Seki, T., Troy, F. A. II, and Inoue, Y. (1995) J. Biol. Chem. 270, 18923-18928

25. Hallenbeck, P. C., Vimer, E. R., Yu, F., Basseler, B., and Troy, F. A. (1987) J. Biol. Chem. 262, 3553-3561

26. Pelkonen, S., Perkonen J., and Finne, J. (1989) J. Virol. 63, 4409-4416

27. Miyake, K.,Muraki, T., Hattori, K., Machida, Y., Watanabe, M., Kawase, M., Yoshida, Y., and Iijima, S. (1997) J. Ferm. Bioeng. 84, 90-93

28. Saito, M., and Yu, R. K. (1995) in Biology of the Sialic Acids (Rosenberg, A., ed.) pp261-313, Plenum Press, New York and London

29. Sato, C., Matsuda, T., and Kitajima K. (2002) J. Biol. Chem. 277, 45299-45305

30. Kitajima, K., Sato, C., Honda, N., Matsuda, T., Yokoyama, M.-H., Close, B. E., and Colley K. J. (1999) in Sialobiology and Other Novel Forms of Glycosylation (Inoue, Y., Lee, Y. C., and Troy, F. A., eds.), pp.69-76, Gakushin Publishing Co., Osaka, Japan 
31. Sato, C., Yasukawa, Z., Honda, N., Matsuda, T., and Kitajima, K. (2001) J. Biol. Chem. 276, 28849-28856

32. Nadanaka, S., Sato, C., Kitajima, K., Katagiri, K, Irie, S., and Yamagata T. (2001) J. Biol. Chem. 276, 33657-33664

33. Yabe, U., Sato, C., and Kitajima, K. (2003) J. Biol. Chem. 278, 13875-13880

34. Miyata, S., Sato, C., Kitamura, S., Toriyama, and Kitajima, K. (2004) Glycobiology 14, 827-840

35. Sato, C., Matsuda, T., and Kitajima K. (2004) in preparation

36. Yasukawa, Z., Sato, C., and Kitajima, K. (2004) submitted

37. Wang, X., Sun, P., Al-Qamari, A., Tai, T., Kawashima, I., and Paller, A.S. (2001) J. Biol. Chem. 276, $8436-8444$

38. B.Wang, J.Brand-Miller, P. McVeagh \& P. Petocz (2001) Am. J. Clin. Nutr. 74, 510-515

39. B.L.G.Morgan \& M.Winick (1980) J. Nutr. 110, 416-424

40. I.H.Mather (2000) J. Dairy Sci. 83, 203-247

41. J.Han, D.P.Hajjar, M.Febbraio \& A.Nicholson (1997) J. Biol. Chem. 272 21654-21659

42. Nohara, K., Kunimoto, M., and Fujimaki, H. (1998) J. Biochem. 124, 194-199

43. Fukuda, M. N., Dell, A., Oates, J. E., and Fukuda, M. (1985) J. Biol. Chem. 260, 6623-6631

44. Inoue, S., Poongodi, G. L., Suresh, N., Jennings, H. J., and Inoue, Y. (2003) J. Biol. Chem. 278, 8541-8546

45. Tsuji, S. (1999) in Sialobiology and Other Novel Forms of Glycosylation (Inoue, Y., Lee, Y. C., and Troy, F. A., eds.) pp.145-154, Gakushin Publishing Co., Osaka

46. Angata, K., and Fukuda, M. (2003) Biochimie 85, 195-206

47. Asahina, S., Matsuno, M., Sato, C., and Kitajima, K. (2004) in preparation

48. Eckhardt, M., Bukalo, O., Chazal, G., Wang, L., Goridis, C., Schachner, M., Gerardy-Schahn, R., Cremer, H., and Dityatev, A. (2000) J. Neurosci. 20, 5234-5244

49. Angata, K., Long, J. M., Bukalo, O., Lee, W., Dityatev, A., Wynshaw-Boris, A., Schachner, M., Fukuda, M., and Marth, J. D. (2004) J. Biol. Chem. 279, in press

50. Yoshida, Y. , Kojima, N., Kurosawa, N., Hamamoto, T., and Tsuji, S. (1995) J. Biol. Chem. 270, 14628-14633

51. Takashima, S., Ishida, H. K., Inazu, T., Ando, T., Ishida, H., Kiso, M., Tsuji, S., and Tsujimoto, M. (2002) J. Biol. Chem. 277, 24030-24038

52. Varki, A.(1999) in Essentials of Glycobiology (Varki, A., Cummings, R., Esko, J., Freeze, H., Hart, G., and Marth, J. eds.) pp.195-209, Cold Spring Harbor Laboratory Press (New York)

53. Rapoport, E., Mikhalyov, I., Zhang, J., Crocker, P., and Bovin, N. (2003) Bioorg. Med. Chem. Lett. 13, 675-678

54. Angata, T., Kerr, S. C., Greaves, D. R., Varki, N. M., Crocker, P. R., and Varki, A. (2001) J. Biol.Chem. 277, 24466-24474

55. Ito, A., Handa, K., Withers, D. A., Satoh, M., and Hakomori, S. (2001) FEBS Lett. 504, 82-86

56. Yamaji, T., Teranishi, T., Alphey, M. S., Crocker, P. R., and Hashimoto, Y.(2002) J. Biol. Chem. 277, 6324-6332

57. Angata T, Kerr SC, Greaves DR, Varki NM, Crocker PR, and Varki A. (2002) J. Biol. Chem. 277 24466-24474

58. Zuber, C., Lackie, P. M., Catterall, W. A., and Roth, J. (1992) J. Biol. Chem. 267, 9965-9971

59. Ziak, M., Kerjaschki, D., Farquhar, M. G., and Roth, J. (1999) J. Am. Soc. Nephrol 10, 203-209

60. Ziak, M., Meier, M., Novak-Hofer, I., and Roth J. (2002) Biochem. Biophys. Res. Commun. 295, 597-602

61. Nagai, Y., and Iwamori, M. (1995) Cellular biology of gangliosides. in Biology Sialic Acids (Rosenberg, A. ed.) pp.194-241

62.Kitazume-Kawaguchi, S., Inoue, S., Inoue, Y., and Lennarz, W. J. (1997) Proc. Nat. Acad. Sci. USA 94, 3650-3655

63. Kiang, W. K., Krusius, T., Finne, J., Margolis, R. U., and Margolis, R. K. (1982) J. Biol. Chem. 257, 1651-1659

64. Fukuda, M., Dell, A., and Fukuda, M. N. (1984) J. Biol. Chem. 259, 4782-4791

65. Fukuda, M., Lauffenburger, M., Sasaki, H., Roger, M. E., and Dell, A. (1987) J. Biol. Chem. 262, 11952-11957

66. Zhang, G., Ji, L., Kurono, S., Fujita, S. C., Furuya, S., and Hirabayashi, Y. (1997) Glycoconjugate J. 14, 847-857

67. Sato, C., Matsuda, T., and Kitajima K. (2004) in preparation

Received on June 3, 2004, accepted on June 7, 2004

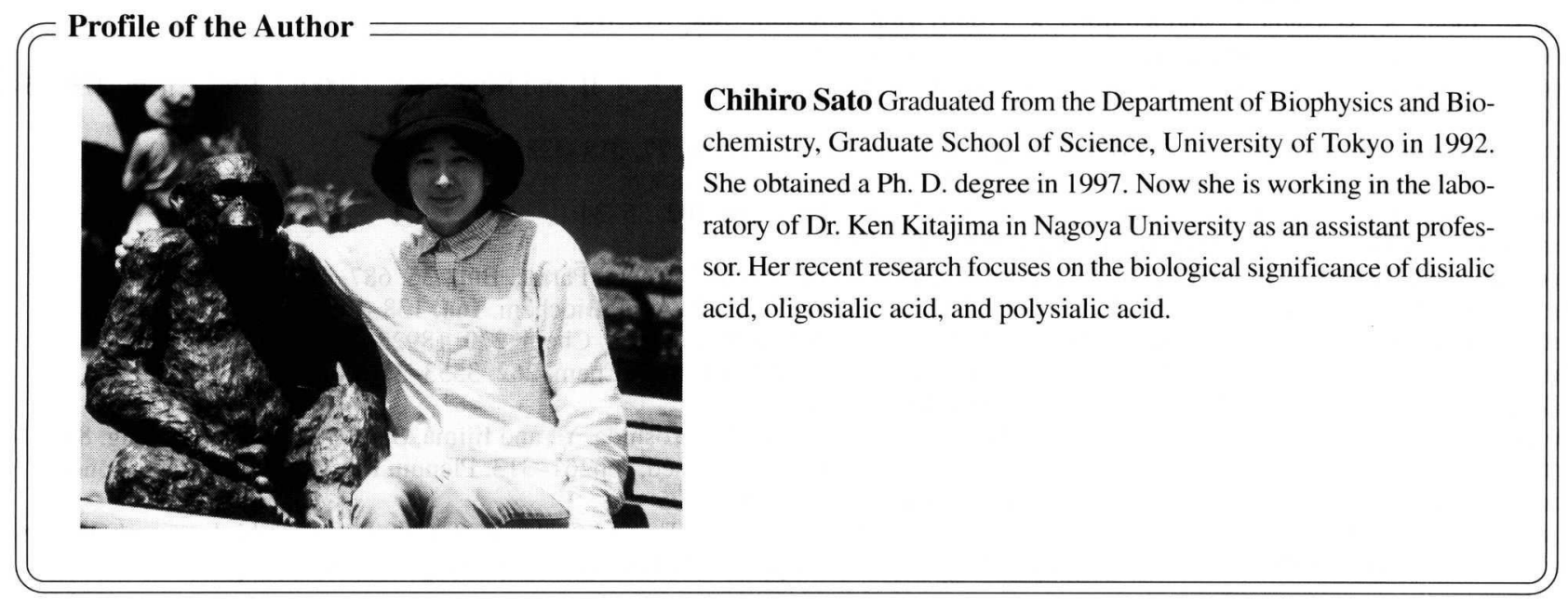

